\title{
Pyrolysis Temperature-Dependent Changes in the Characteristics of Biochar-Borne Dissolved Organic Matter and Its Copper Binding Properties
}

\author{
Jing Wei ${ }^{1,2} \cdot$ Chen $\mathrm{Tu}^{1,2} \cdot$ Guodong Yuan ${ }^{3} \cdot$ Dongxue $\mathrm{Bi}^{1,2} \cdot$ Hailong Wang ${ }^{4} \cdot$ Lijuan Zhang $^{5} \cdot$ Benny K. G. Theng ${ }^{6}$
}

Received: 3 May 2018 / Accepted: 28 June 2018 / Published online: 7 July 2018

(c) Springer Science+Business Media, LLC, part of Springer Nature 2018

\begin{abstract}
The dissolved organic matter (DOM) samples from biochars produced from Jerusalem artichoke stalks by pyrolysis at 300, 500 , and $700{ }^{\circ} \mathrm{C}$ were characterized using a combination of spectroscopic techniques. Additionally, the binding affinities (long $\mathrm{K}_{\mathrm{M}}$ ) and the complexation capacities $\left(\mathrm{C}_{\mathrm{L}}\right)$ of the DOM samples with $\mathrm{Cu}(\mathrm{II})$ were calculated to assess their $\mathrm{Cu}$ binding properties. The biochar-borne DOM contained mainly humic-like components (C1-C3) with a small amount of a protein-like component (C4). As the charring temperature increased, the concentrations of released DOM decreased. The low temperature biochar-borne DOM was found to have more carboxyl groups than its high temperature counterparts, and thus it had larger $\mathrm{C}_{\mathrm{L}}$ values. In contrast, the high temperature biochar-borne DOM had larger long $\mathrm{K}_{\mathrm{M}}$ values. Low temperature biochars, if applied in a large quantity, would alter copper mobility in the environment because of their high DOM contents and large copper binding capacities.
\end{abstract}

Keywords Biochar $\cdot$ DOM $\cdot$ EEM $\cdot$ PARAFAC $\cdot$ C K-NEXAFS $\cdot$ Copper-binding

Biochar has recently been used to improve soil quality, reduce toxic contaminant accumulation in crops, and remediate contaminated soil because of its unique physicochemical properties (Mehmood et al. 2018; Shu et al. 2016). With the increasing application in the soil environment, biochar may release a large amount of dissolved organic matter

Guodong Yuan

yuanguodong@zqu.edu.cn

1 Key Laboratory of Coastal Environmental Processes and Ecological Remediation, Yantai Institute of Coastal Zone Research (YIC), Chinese Academy of Sciences (CAS), Yantai 264003, China

2 Shandong Provincial Key Laboratory of Coastal Environmental Processes, YICCAS, Yantai 264003, China

3 School of Environmental and Chemical Engineering, Zhaoqing University, Zhaoqing 526061, China

4 School of Environment and Chemical Engineering, Foshan University, Foshan 528000, China

5 Shanghai Synchrotron Radiation Facility, Shanghai Institute of Applied Physics, Chinese Academy of Sciences, Shanghai 201204, China

6 Landcare Research, Private Bag 11052, Palmerston North 4442, New Zealand
(DOM) into soil pore waters. Biochar-borne DOM has been shown to have different composition, structure, mobility, and environmental reactivity in comparison to bulk biochar. For example, DOM has more polar and redox-active functional groups, such as carboxylic and phenolic groups, than does bulk biochar (Qu et al. 2016). Therefore, DOM released from biochar could bind with heavy metals and could serve as a carrier to facilitate their transport in soil (Uchimiya et al. 2010). On a global scale, adding biochar to soil would therefore enhance the amount of DOM leached into rivers and the marine environment (Jaffe et al. 2013). In view of the important role that DOM could play in soil biogeochemical reactions, there is an urgent need to improve our understanding of the chemical changes in biochar-borne DOM that occur at the molecular level. Moreover, it is equally important to understand how the dynamic variations in the chemical composition of biochar-borne DOM may influence the interaction between the DOM and heavy metals.

As biochar-borne DOM consists of organic molecules with variable molecular size and functional groups, multiple analytical techniques have been applied to characterize this complex material. Using UV-visible absorption spectroscopy, Jamieson et al. (2014) found that biochar-borne DOM, prepared via fast pyrolysis at $600{ }^{\circ} \mathrm{C}$, was more aromatic and 
larger in mean molecular weight than DOM from biochar obtained by slow pyrolysis at $350{ }^{\circ} \mathrm{C}$. Lin et al. (2012) used liquid chromatography-organic carbon detection to quantify the content of five organic fractions, including humics, oxidation products of humics, proteins (aminosugars), low molecular weight acids and neutrals in DOM extracted from four biochar samples. Humic-like, fulvic-like, and proteinlike substances were the major fluorescent components identified from biochar-borne DOM by fluorescence excitationemission matrix (EEM) spectroscopy coupled with parallel factor analysis (PARAFAC) (Jamieson et al. 2014; Uchimiya et al. 2013). Solid-state ${ }^{13} \mathrm{C}$ nuclear magnetic resonance $\left({ }^{13} \mathrm{C}\right.$ NMR) spectroscopic analysis indicated that dissolved carbon fractions, released from rice and bamboo biochars, were mainly composed of aromatic blocks containing carboxyl groups and some phenolic groups (Qu et al. 2016).

The composition of biochar-borne DOM is governed by the feedstock type and the pyrolysis temperature (Uchimiya et al. 2013)and greatly influenced by the extraction conditions ( $\mathrm{Li}$ et al. 2017). Despite the above examples of work done to characterize DOM, the chemical changes in biocharborne DOM at the molecular level and their environmental risks have not been fully and systematically investigated. The aims of this study were: (1) to elucidate the dynamic changes in the chemical composition and molecular structure of DOM extracted from biochar produced at varying temperatures; and (2) to investigate the binding characteristics of the DOM with heavy metal $\mathrm{Cu}(\mathrm{II})$.

\section{Materials and Methods}

Jerusalem artichoke is an economic crop that has been widely cultivated in salinized land in Northern China. The growing production has aroused environmental problems for the treatment of Jerusalem artichoke stalks (JAS) wastes. Therefore, preparing biochar from JAS becomes an emerging pathway to the disposal of agricultural waste. The JAS feedstock were collected from an experimental field near Yantai city, Shandong Province. A powdered feedstock was packed into a ceramic crucible, heated with a rate of $5^{\circ} \mathrm{C} /$ min to 300,500 or $700{ }^{\circ} \mathrm{C}$ in an electric quartz tube furnace under $300 \mathrm{~mL} / \mathrm{min}$ purified nitrogen $(99.99 \%)$ flow, and then pyrolyzed for $6 \mathrm{~h}$ to produce biochars.

DOM samples were extracted by Milli-Q water at a biochar to water ratio of $1: 100 \mathrm{~m} / \mathrm{v}$ for $48 \mathrm{~h}$ on a horizontal shaker at room temperature in the dark. The biochar-water mixtures were then filtered through $0.45 \mu \mathrm{m}$ polytetrafluoroethylene (PTFE) membranes. The DOM samples obtained were labeled JAS300, JAS500, and JAS700. DOM samples were obtained from each biochar in triplicate and then divided into two parts for further analysis: one part was stored in a brown glass bottle at $4{ }^{\circ} \mathrm{C}$, and the other part was freeze-dried and stored in a desiccator.

The DOM samples were analyzed for dissolved organic carbon (DOC) using a TOC/TN analyzer (TOC-VCPH, Shimadzu, Japan). The detection limit of the TOC/TN analyzer is $0.5 \mathrm{mg} / \mathrm{L}$. Potassium biphthalate and mixture solution of sodium carbonate and sodium bicarbonate were used as reference materials for total carbon and inorganic carbon detection, respectively. The DOC was calculated by the total carbon minus the inorganic carbon.

The Carbon K-edge NEXAFS data were collected using the soft X-ray spectromicroscopy beamline (BL08U1A) at the Shanghai Synchrotron Radiation Facility (SSRF), China. C K-edge NEXAFS data of each DOM samples were recorded at total electron yield (TEY) mode from 280 to $310 \mathrm{eV}$ in steps of $0.1 \mathrm{eV}$. The normalized NEXAFS spectra were deconvoluted by the PeakFit v4.12 (SeaSolve) using the deconvolution scheme modified from Schumacher et al. (2005). Peak assignments for C K-edge NEXAFS adapted from Keiluweit et al. (2010), Singh et al. (2014), and Solomon et al. (2012).

Fluorescence quenching titration was performed following the method of Wei et al. (2015). Briefly, the DOM solutions were first diluted to give DOC concentrations of 9.9, 10.6, and $6.1 \mathrm{mg} / \mathrm{L}$ for JAS300, JAS500, and JAS70, respectively, in order to minimize the fluorescence innerfilter effect. Aliquots of $25 \mathrm{~mL}$ of the DOM samples were titrated with stock solutions using a HandyStep ${ }^{\circledR}$ Tripette in $40 \mathrm{~mL}$ brown vials. The $\mathrm{Cu}$ (II) concentrations in the final solutions ranged from 0 to $100 \mu \mathrm{mol} / \mathrm{L}$. Each treatment was conducted in triplicate. All titrated solutions were adjusted to $\mathrm{pH} 6.0 \pm 0.1$ using $\mathrm{HNO}_{3}$ or $\mathrm{NaOH}$, and then shaken at $25^{\circ} \mathrm{C}$ for $24 \mathrm{~h}$ to achieve complexation equilibrium.

Biochar DOM samples were measured using an Aqualog spectrometer (Aqualog, HORIBA, Japan) to obtain fluorescence EEMs. The emission wavelength (Em) range was set from 245 to $825 \mathrm{~nm}$ in steps of $1 \mathrm{~nm}$, and the excitation wavelength (Ex) range was set from 200 to $450 \mathrm{~nm}$ in steps of $5 \mathrm{~nm}$. Raman scatter and the Rayleigh scattering effects were automatically eliminated by Aqualog ${ }^{\circledR}$ package software. The arbitrary units of the EEMs were then normalized using the integrated area of the blank Milli-Q water Raman peak located at $E x=350 \mathrm{~nm}$. The PARAFAC modeling is described in detail elsewhere (Wei et al. 2015).

The modified Ryan-Weber model was applied to determine the complexation parameters, including the conditional stability constant $\left(\mathrm{K}_{\mathrm{M}}\right)$ and the stoichiometric concentration of the ligand $\left(\mathrm{C}_{\mathrm{L}}\right)$ between the PARAFAC derived components and $\mathrm{Cu}$. Description of the equation is detailed elsewhere (Luster et al. 1996). Origin 9.1 software (OriginLab) was used for fitting parameters.

Statistical analyses were carried out using the SPSS 19.0 software package (IBM). Significant differences were tested 
using one-way ANOVA with Duncan's multiple range test at the $5 \%$ level.

\section{Results and Discussion}

The amount of DOM (counted as DOC) released from JAS biochars decreases with rising pyrolysis temperatures (Table 1). These findings are consistent with those from previous studies where water-extractable organic carbon concentrations in sawdust biochar declined from $9.34 \times 10^{-2}$ to $4.29 \times 10^{-3} \mathrm{~g} \mathrm{C} / \mathrm{kg}$ as the pyrolysis temperature increased from 450 to $500{ }^{\circ} \mathrm{C}$ (Lin et al. 2012). Xiao et al. (2014) also reported a steady decrease in DOC concentration in rice-straw biochar as the pyrolysis temperature increased from 150 to $700{ }^{\circ} \mathrm{C}$. These indicated that biochar becomes aromatized and condensed at high pyrolysis temperatures $\left(500-700{ }^{\circ} \mathrm{C}\right)$, causing a marked decrease in water-soluble carbon.

Pyrolysis temperature affected not only the contents of biochar-borne DOM, but also the organic functional groups species of the DOM. Carbon K-edge NEXAFS spectra of each DOM samples are displayed in Fig. 1 for functional groups identification. The pattern of the biochar DOM spectra is similar to those spectra of bulk biochars (Keiluweit et al. 2010; Lin et al. 2018; Singh et al. 2014; Solomon et al. 2012) and soil organic substances (Luo et al. 2017), which indicates a similarity in their organic $\mathrm{C}$ speciation. However, the spectral intensities are different. This suggests that the relative abundances of $\mathrm{C}$ species are various. For semiquantitative comparison of $\mathrm{C}$ speciation present in the DOM released from biochars, the relative proportions of the primary $\mathrm{C}$ species were derived by spectra fitting of the corresponding peaks (Fig. 1; Table 2). The relative proportions of $\mathrm{C}$ species of the biochar-borne DOM (Table 2) indicate
Table 1 Dissolved organic carbon (DOC) in biochar water extracts

\begin{tabular}{lllc}
\hline Biochar-borne DOM $(\mathrm{pH})$ & DOC $(\mathrm{mg} / \mathrm{g}$ of biochar $)$ & $\begin{array}{l}\text { Total solute }(\mathrm{mg} / \mathrm{g} \text { of } \\
\text { biochar }\end{array}$ & $\begin{array}{l}\text { \% DOC in } \\
\text { total solute }\end{array}$ \\
\hline JAS300 $(\mathrm{pH} \mathrm{7.07} \pm 0.13)$ & $23.00 \pm 1.01^{\mathrm{a}}$ & $85.2 \pm 7.4^{\mathrm{a}}$ & 27.0 \\
JAS500 $(\mathrm{pH} \mathrm{7.84} \pm 0.15)$ & $0.55 \pm 0.16^{\mathrm{b}}$ & $14.4 \pm 1.7^{\mathrm{b}}$ & 3.8 \\
JAS700 $(\mathrm{pH} \mathrm{7.73 \pm 0.23)}$ & $0.20 \pm 0.03^{\mathrm{b}}$ & $13.0 \pm 1.4^{\mathrm{b}}$ & 1.6 \\
\hline
\end{tabular}

Data are presented as the mean $\pm \mathrm{SD}$

${ }^{\mathrm{a}, \mathrm{b}}$ Indicate significant differences $(p<0.05)$
Fig. 1 Speciation of biocharC K-edge NEXFAS spectra deconvolution showing the main $1 \mathrm{~s}-\pi^{*}$ and $1 \mathrm{~s}-3 \mathrm{p} / \sigma^{*}$ transitions, $\sigma^{*}$ transitions, and arctangent step functions borne DOM using typical

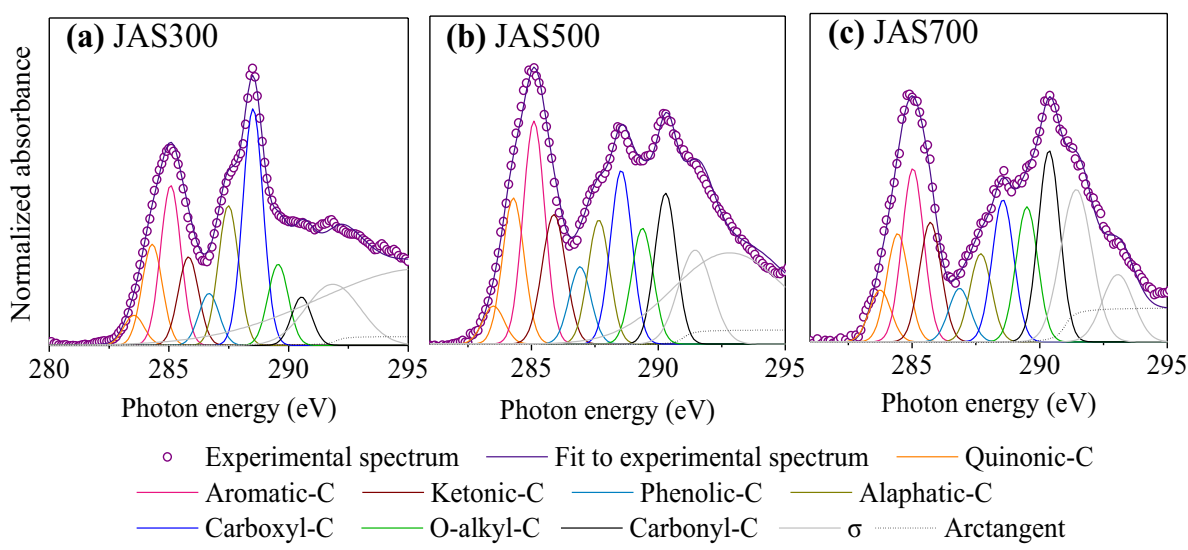

Table 2 Organic C species proportions (\%) of biochar-borne DOM identified by C K-edge NEXAFS spectra

\begin{tabular}{|c|c|c|c|c|c|c|c|c|}
\hline \multirow{2}{*}{$\begin{array}{l}\text { Biochar- } \\
\text { borne DOM }\end{array}$} & \multicolumn{8}{|l|}{$\mathrm{C}$ species $(\mathrm{eV})$} \\
\hline & $\begin{array}{l}\text { Quinonic- } \\
(283.5-284.3)\end{array}$ & $\begin{array}{l}\text { Aromatic- } \\
(284.8-285.3)\end{array}$ & $\begin{array}{l}\text { Ketonic- } \\
(285.7-286.2)\end{array}$ & $\begin{array}{l}\text { Phenolic- } \\
(286.6-287.1)\end{array}$ & $\begin{array}{l}\text { Aliphatic- } \\
(287.5-287.9)\end{array}$ & $\begin{array}{l}\text { Carboxyl- } \\
(288.2-288.6)\end{array}$ & $\begin{array}{l}\text { O-alkyl- } \\
(288.8-289.5)\end{array}$ & $\begin{array}{l}\text { Carbonyl- } \\
(290.0- \\
290.5)\end{array}$ \\
\hline JAS300 & 14.0 & 17.0 & 9.4 & 5.5 & 14.9 & 25.2 & 8.7 & 5.2 \\
\hline JAS500 & 15.5 & 18.7 & 11.9 & 6.5 & 10.4 & 14.6 & 9.7 & 12.7 \\
\hline JAS700 & 15.1 & 16.3 & 11.2 & 5.0 & 8.3 & 13.4 & 12.7 & 18.0 \\
\hline
\end{tabular}


that the total aromatic- $\mathrm{C}$, including the quinonic $\mathrm{C}=\mathrm{O}$ and aromatic $\mathrm{C}=\mathrm{C}$, comprises the most prominent species. The aromatic-C species accounts for $31.0 \%-34.2 \%$ of the total $\mathrm{C}$ for JAS biochar DOM. These portions of total aromatic$\mathrm{C}$ are comparable with those reported in soil humic acid (32.9\%) and peat fulvic acid (25.2\%) (Schumacher 2005), but lower than that in black carbon particles (41\%) collected from anthrosols (Heymann et al. 2014). Using ${ }^{13} \mathrm{C}$ NMR spectroscopy, Qu et al. (2016) found that dissolved black carbon contained less aromatic structures. However, it did contain 30\%-40\% more carboxyl and phenolic groups than bulk biochar (produced at $400{ }^{\circ} \mathrm{C}$ ). In this study, biocharborne DOM contains only contained $8.9 \%-25.2 \%$ of carboxyl-C, unlike the soil humic and fulvic fractions which have 29.5\%-51.8\% carboxyl-C (Schumacher 2005).

The relative proportions of different $\mathrm{C}$ species in the DOM from JAS biochars are influenced by charring temperature. As shown in the C NEXAFS spectra (Fig. 1), the absorption bands of carboxyl-C and aliphatic-C weaken as the charring temperature increases. These changes are also reflected by their proportions listed in Table $2.500{ }^{\circ} \mathrm{C}$ is a critical point for the formation or decomposition of carboxyl groups. During the pyrolysis process, carboxyl groups were formed by the oxidation of free primary hydroxyls at $\leq 500{ }^{\circ} \mathrm{C}$, and were subsequently consumed via dehydrogenation and dihydroxylation at temperatures $>500{ }^{\circ} \mathrm{C}$ (Harvey et al. 2012). Differently, the proportions of quinonic$\mathrm{C}$ and phenolic-C do not change appreciably from 300 to $700{ }^{\circ} \mathrm{C}$. Based on above results, it can be expected that DOM from $300{ }^{\circ} \mathrm{C}$ biochar, which has abundant oxygen-containing functional group (including carboxyl and phenolic groups), may have large binding capacity for heavy metals.

In order to elucidate the binding properties of biocharborne DOM with $\mathrm{Cu}$, the main functional components in the DOM and their individual $\mathrm{Cu}$ binding behaviors were studied by EEM-PARAFAC and fluorescence quenching titration. Four fluorescent components were identified by PARAFAC from JAS biochar-borne DOM (Fig. 2). The EEM spectral loadings of PARAFAC components modeled with the halves of the dataset and on the whole dataset of JAS biochar DOM coincided quite well, indicating a suitable PARAFAC analysis. The Ex and Em peaks of the four components were compared with those found in previous PARAFAC analyses of biochar-borne DOM (Jamieson et al. 2014; Li et al. 2017; Uchimiya et al. 2016, 2013) and of DOM in natural systems (Ishii and Boyer 2012). These four components were categorized into three humiclike components $(\mathrm{C} 1, \mathrm{C} 2, \mathrm{C} 3)$ and a protein-like component (C4). The $\mathrm{C} 1$ component displayed two Ex peaks (at $370 \mathrm{~nm}$ and $<230 \mathrm{~nm}$ ), corresponding to a single Em peak (at $445 \mathrm{~nm}$ ). The $\mathrm{C} 2$ component had a major Ex peak at $325 \mathrm{~nm}$ with a single Em peak at $385 \mathrm{~nm}$. The C3 component showed a single Ex peak below $230 \mathrm{~nm}$ with a broad Em peak centered between 400 and $500 \mathrm{~nm}$. The proteinlike $\mathrm{C} 4$ component had a distinct Ex peak at $285 \mathrm{~nm}$ and an Em peak between 310 and $375 \mathrm{~nm}$.

The corresponding fluorescence intensities and relative abundances of the four components are presented in Table 3. Humic fractions account for the main part of the biochar-borne DOM. In this study, $\mathrm{Cu}$ titration led to fluorescence quenching for all the four components. Table 3 summarizes the complexation parameters between each DOM component and $\mathrm{Cu}$ by using the modified Ryan-Weber model. The $\mathrm{C}_{\mathrm{L}}$ values (i.e., the complexation capacities) of the four components decreased as the charring temperature increased (Table 3). Carboxyl groups in humic substances usually serve as major complexing sites for heavy metals under $\mathrm{pH} 6.0$ (i.e., this experimental conditions) (Meng et al. 2017). Meanwhile, the NEXAFS results exhibited a declining trend in the carboxyl content of biochar DOM, which reveals a decrease in available complexing ligands. Thus, it could be concluded that $\mathrm{Cu}$ interactions with biochar DOM are mainly due to the complexation between $\mathrm{Cu}$ and carboxyl groups of humic fractions. DOM from a low temperature biochar has a higher content of carboxyl groups and thus a larger complexation capacity than those from a high temperature biochar.
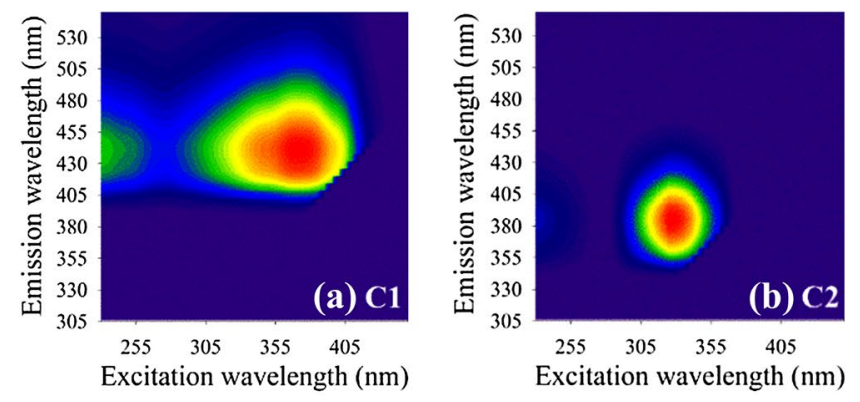
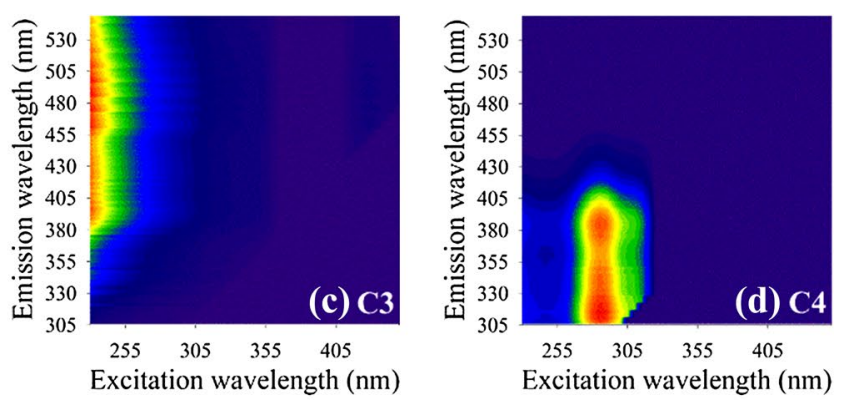

Fig. 2 The EEM contours of PARAFAC components modeled with the datasets of JAS biochar DOM. C1, C2, and C3 refer to three humic-like components, and $\mathrm{C} 4$ refers to the protein-like component, respectively 
Table 3 The corresponding fluorescence intensities and relative abundances of the PARAFAC-derived components and their binding parameters with $\mathrm{Cu}(\mathrm{II})$

\begin{tabular}{|c|c|c|c|c|c|c|}
\hline \multirow{2}{*}{$\begin{array}{l}\text { Biochar- } \\
\text { borne DOM }\end{array}$} & \multirow{2}{*}{$\begin{array}{l}\text { PARAFAC } \\
\text { components }\end{array}$} & \multirow{2}{*}{$\begin{array}{l}\text { Fluorescence inten- } \\
\text { sity }(A U / D O C \pm S D)\end{array}$} & \multirow{2}{*}{$\begin{array}{l}\text { Fluores- } \\
\text { cence }(\%)\end{array}$} & \multicolumn{3}{|c|}{ Binding parameters } \\
\hline & & & & $\log K_{M}$ & $\mathrm{C}_{\mathrm{L}}\left(\mu \mathrm{mol} \mathrm{L}^{-1}\right)$ & $\mathrm{R}^{2}$ \\
\hline \multirow[t]{4}{*}{ JAS300 } & $\mathrm{C} 1$ & $13.0 \pm 0.4^{\mathrm{a}}$ & 38.1 & 4.65 & 69.1 & 0.987 \\
\hline & $\mathrm{C} 2$ & $6.4 \pm 0.4^{\mathrm{a}}$ & 18.8 & 4.66 & 68.5 & 0.990 \\
\hline & $\mathrm{C} 3$ & $7.8 \pm 0.4^{b}$ & 22.8 & 5.04 & 17.5 & 0.929 \\
\hline & $\mathrm{C} 4$ & $6.9 \pm 0.2^{\mathrm{a}}$ & 20.3 & 4.38 & 93.2 & 0.985 \\
\hline \multirow[t]{4}{*}{ JAS500 } & $\mathrm{C} 1$ & $1.8 \pm 0.2^{\mathrm{b}}$ & 9.5 & Not modeled * & & \\
\hline & $\mathrm{C} 2$ & $3.3 \pm 0.3^{\mathrm{b}}$ & 17.0 & 4.82 & 40.7 & 0.905 \\
\hline & $\mathrm{C} 3$ & $11.3 \pm 0.6^{\mathrm{a}}$ & 58.0 & 4.98 & 17.4 & 0.977 \\
\hline & $\mathrm{C} 4$ & $3.0 \pm 0.6^{\mathrm{b}}$ & 16.5 & Not modeled & & \\
\hline \multirow[t]{4}{*}{ JAS700 } & $\mathrm{C} 1$ & Not detected & 0 & Not modeled & & \\
\hline & $\mathrm{C} 2$ & Not detected & 0 & Not modeled & & \\
\hline & $\mathrm{C} 3$ & $4.0 \pm 0.2^{\mathrm{c}}$ & 74.9 & 6.06 & 9.87 & 0.942 \\
\hline & $\mathrm{C} 4$ & $1.3 \pm 0.6^{\mathrm{b}}$ & 25.1 & Not modeled & & \\
\hline
\end{tabular}

*The quenching curve fitting was not performed because the detected fluorescence intensities of these component were too low and the fitting failed

${ }^{\mathrm{a}, \mathrm{b}, \mathrm{c}}$ Indicate significant differences for each component under different temperatures $(p<0.05)$
The $\log \mathrm{K}_{\mathrm{M}}$ values for $\mathrm{C} 1-\mathrm{C} 4$ in DOM from JAS biochars vary from 4.38 to 6.06 , close to the values reported in previous studies on soil- and freshwater-borne DOM (Hu et al. 2017; Wei et al. 2015). The $\log \mathrm{K}_{\mathrm{M}}$ values exhibit a rising trend with increasing charring temperature, indicating that components of DOM from high temperature biochars would have higher binding affinities for $\mathrm{Cu}$ compared to their low temperature counterparts. The $\log \mathrm{K}_{\mathrm{M}}$ and $\mathrm{C}_{\mathrm{L}}$ values of humic-like components are largely different from those of protein-like component. The mechanism underlying the diversity in binding affinities between biochar-borne DOM components and $\mathrm{Cu}$ is still unclear. The different proportions of the functional groups in specific DOM components interact differently with $\mathrm{Cu}$, and the speciation of the formed complexes merit further study.

The present study reveals the temperature-dependent changes in chemical composition and molecular structure of DOM from lignocellulose-rich biomass-derived biochars. Higher charring temperatures (from 300 to $700{ }^{\circ} \mathrm{C}$ ) decreased the concentration of biochar-borne DOM. The relative proportion of humic-like components, associated with abundant aromatic structures, however, increased with rising charring temperature. At the molecular level, the higher charring temperature led to a decrease in the content of carboxyl and aliphatic groups of the biochar-borne DOM. Being enriched with carboxyl groups, low temperature biochar-borne DOM had larger complexation capacities than its high temperature counterparts. Considering its relatively high concentrations of carboxyl groups, low temperature biochar-borne DOM would be expected to play a significant role in controlling $\mathrm{Cu}$ bioavailability and mobility in soil systems.
Acknowledgements This research was supported by the National Natural Science Foundation of China (41501522), the Chinese National Key Research and Development Program (2016YFD0200303 and 2016YFE0106400), and the National High Technology Research and Development Program (2012AA06A204-4).

\section{References}

Harvey OR, Herbert BE, Kuo LJ, Louchouarn P (2012) Generalized two-dimensional perturbation correlation infrared spectroscopy reveals mechanisms for the development of surface charge and cecalcitrance in plant-derived biochars. Environ Sci Technol 46:10641-10650. https://doi.org/10.1021/es302971d

Heymann K, Lehmann J, Solomon D, Liang B, Neves E, Wirick S (2014) Can functional group composition of alkaline isolates from black carbon-rich soils be identified on a sub- $100 \mathrm{~nm}$ scale? Geoderma 235-236:163-169. https://doi.org/10.1016/j.geode rma.2014.07.011

Hu B, Wang PF, Wang C, Qian J, Hou J, Cui XA, Zhang NN (2017) The effect of anthropogenic impoundment on dissolved organic matter characteristics and copper binding affinity: Insights from fluorescence spectroscopy. Chemosphere 188:424-433. https:// doi.org/10.1016/j.chemosphere.2017.09.023

Ishii SKL, Boyer TH (2012) Behavior of reoccurring PARAFAC components in fluorescent dissolved organic matter in natural and engineered systems: A critical review. Environ Sci Technol 46:2006-2017. https://doi.org/10.1021/es2043504

Jaffe R, Ding Y, Niggemann J, Vahatalo AV, Stubbins A, Spencer RGM, Campbell J, Dittmar T (2013) Global charcoal mobilization from soils via dissolution and riverine transport to the oceans. Science 340:345-347. https://doi.org/10.1126/science. 1231476

Jamieson T, Sager E, Gueguen C (2014) Characterization of biocharderived dissolved organic matter using UV-visible absorption and excitation-emission fluorescence spectroscopies. Chemosphere 103:197-204. https://doi.org/10.1016/j.chemosphere.2013.11.066

Keiluweit M, Nico PS, Johnson MG, Kleber M (2010) Dynamic molecular structure of plant biomass-derived black carbon (biochar). Environ Sci Technol 44:1247-1253. https://doi.org/10.1021/es903 1419 
Li M, Zhang AF, Wu HM, Liu H, Lv JL (2017) Predicting potential release of dissolved organic matter from biochars derived from agricultural residues using fluorescence and ultraviolet absorbance. J Hazard Mater 334:86-92. https://doi.org/10.1016/j.jhazm at.2017.03.064

Lin Y, Munroe P, Joseph S, Henderson R, Ziolkowski A (2012) Water extractable organic carbon in untreated and chemical treated biochars. Chemosphere 87:151-157. https://doi.org/10.1016/j.chemo sphere.2011.12.007

Lin Q, Xu X, Chen Q, Fang J, Shen XD, Zhang LJ (2018) Changes in structural characteristics and metal speciation for biochar exposure in typic udic ferrisols. Environ Sci Pollut R 25:153-162. https ://doi.org/10.1007/s11356-017-8634-0

Luo L, Lv JT, Chen Z, Huang RX, Zhang SZ (2017) Insights into the attenuated sorption of organic compounds on black carbon aged in soil. Environ Pollut 231:1469-1476. https://doi.org/10.1016/j. envpol.2017.09.010

Luster J, Lloyd T, Sposito G, Fry IV (1996) Multi-wavelength molecular fluorescence spectrometry for quantitative characterization of copper(II) and aluminum(III) complexation by dissolved organic matter. Environ Sci Technol 30:1565-1574 doi. https://doi. org/10.1021/Es950542u

Mehmood S, Rizwan M, Bashir S, Ditta A, Aziz O, Yong LZ, Dai ZH, Akmal M, Ahmed W, Adeel M (2018) Comparative Effects of Biochar, Slag and Ferrous-Mn Ore on Lead and Cadmium Immobilization in Soil. B Environ Contam Tox 100:286-292. https:// doi.org/10.1007/s00128-017-2222-3

Meng FD, Yuan GD, Wei J, Bi DX, Wang HL (2017) Leonarditederived humic substances are great adsorbents for cadmium. Environ Sci Pollut R 24:23006-23014. https://doi.org/10.1007/ s11356-017-9947-8

Qu X, Fu H, Mao J, Ran Y, Zhang D, Zhu D (2016) Chemical and structural properties of dissolved black carbon released from biochars. Carbon 96:759-767. https://doi.org/10.1016/j.carbo n.2015.09.106
Schumacher M (2005) Microheterogeneity of soil organic matter investigated by C-1 s NEXAFS spectroscopy and X-ray microscopy. Dissertation, Swiss Federal Institute of Technology Zurich

Shu R, Wang YJ, Zhong H (2016) Biochar amendment reduced methylmercury accumulation in rice plants. J Hazard Mater 33:1-8. https://doi.org/10.1016/j.jhazmat.2016.03.080

Singh B, Fang YY, Cowie BCC, Thomsen L (2014) NEXAFS and XPS characterisation of carbon functional groups of fresh and aged biochars. Org Geochem 77:1-10. https://doi.org/10.1016/j.orgge ochem.2014.09.006

Solomon D et al (2012) Micro- and nano-environments of C sequestration in soil: A multi-elemental STXM-NEXAFS assessment of black $\mathrm{C}$ and organomineral associations. Sci Total Environ 438:372-388. https://doi.org/10.1016/j.scitotenv.2012.08.071

Uchimiya M, Lima IM, Klasson KT, Wartelle LH (2010) Contaminant immobilization and nutrient release by biochar soil amendment: Roles of natural organic matter. Chemosphere 80:935-940. https ://doi.org/10.1016/j.chemosphere.2010.05.020

Uchimiya M, Ohno T, He ZQ (2013) Pyrolysis temperature-dependent release of dissolved organic carbon from plant, manure, and biorefinery wastes. J Anal Appl Pyrolysis 104:84-94. https://doi. org/10.1016/j.jaap.2013.09.003

Uchimiya M, Liu ZZ, Sistani K (2016) Field-scale fluorescence fingerprinting of biochar-borne dissolved organic carbon. J Environ Manage 169:184-190. https://doi.org/10.1016/j.jenvm an.2015.12.009

Wei J, Han L, Song J, Chen MF (2015) Evaluation of the interactions between water extractable soil organic matter and metal cations $(\mathrm{Cu}(\mathrm{II}), \mathrm{Eu}(\mathrm{III}))$ using Excitation-Emission matrix combined with parallel factor analysis. Int J Mol Sci 16:14464-14476. https://doi. org/10.3390/ijms160714464

Xiao X, Chen BL, Zhu LZ (2014) Transformation, morphology, and dissolution of silicon and carbon in rice straw-derived biochars under different pyrolytic temperatures. Environ Sci Technol 48:3411-3419. https://doi.org/10.1021/es405676h 